\title{
Transcription Elongation Factor A Protein 1
}

National Cancer Institute

\section{Source}

National Cancer Institute. Transcription Elongation Factor A Protein 1. NCI Thesaurus. Code C97824.

Transcription elong ation factor A protein 1 (301 aa, $~ 34 \mathrm{kDa}$ ) is encoded by the human TCEA1 gene. This protein is involved in the positive regulation of transcription elongation. 